\title{
Scientific Production on the Social Economy: A Review of Worldwide Research
}

\author{
Antonio José Macías Ruano ${ }^{1} \cdot$ Juan Milán-García $^{2} \cdot$ María Esther Marruecos Rumí $^{1}$. \\ Jaime De Pablo Valenciano ${ }^{2}$
}

Accepted: 17 May 2021/Published online: 9 June 2021

(C) International Society for Third-Sector Research 2021

\begin{abstract}
The aim of this article is to assess the use of the term Social Economy, while being aware of its lack of concreteness, and to analyze the level of scientific production by means of a bibliometric analysis using WoS (JCR) and Scopus (SJR) as sources. Starting in 2004 and related to the Charter of Principles of the Social Economy, the material development of articles began. The most receptive countries are Spain, the USA, China, the UK and Canada. In terms of the most productive journals, Voluntas in JCR and CIRIEC-Spain and REVESCO in SJR stand out. Scientific production on this issue is linked to university institutions, namely the Chinese Academy of Sciences, the University of Valencia and the University of Quebec. The most prevalent subject are Economics and Business in the case of JCR and Social Sciences in SJR. The most recognized term is that of cooperatives and the most prevalent keyword trends being related to sustainable development, climate change, urbanization, management and China.
\end{abstract}

Keywords Social economy - Bibliometric analysis . Scopus - WoS $\cdot$ Third sector

Jaime De Pablo Valenciano

jdepablo@ual.es

Antonio José Macías Ruano

ajmacias@ual.es

Juan Milán-García

jmg483@ual.es

María Esther Marruecos Rumí

mmr646@ual.es

Department of Law, University of Almeria, Almería, Spain

2 Department of Business and Economics, Applied Economic Area, University of Almeria, Almería, Spain

\section{Introduction}

Within the scope of legislative development at an international level, pan-EU institutions, individual Member States, and other leading countries around the world, as well as in the sphere of academic and institutional scientific production, the term Social Economy is acquiring greater prominence for promoting policies and scientific development that are focused on people, the environment and social contexts beyond mere economic growth. Social Economy is only one of several terms used to incorporate nuances, different visions, or more specific objectives related to this field of scientific development.

This article focuses on the term "Social Economy" as a pioneer of a new vision of wealth focused on people and their environment. This notwithstanding, the authors remain cognizant of the ongoing research and analysis being carried out on many other terms associated with scientific, political, legal, and economic content.

Social Economy is a term that the European legislator (Vid. Regulation (EU) 2021/241 of the European Parliament and of the Council, of 12 February 2021, establishing the Recovery and Resilience Facility) is using to define a model of economic development that seeks social and territorial cohesion, sustainability, social justice and the equitable distribution of wealth. In continental western Europe, the social economy is very present at the institutional, legislative, integrated representative groups, and scientific levels. In Spain, there is even a State Government Ministry of Labor and Social Economy. But the fact that the term Social Economy is being used in a legislative, institutional and scientific framework does not mean that it is universally accepted. Such a strong presence of the term in a limited spatial scope may lead to the idea that it has 
universal validity, running the risk of extrapolating a localized concept into a more generalized presence.

Based on the scientific publications that have a worldwide presence, we propose analyzing the term "Social Economy" as understood in continental Western Europe has a similar level of acceptance around the world and determine if it has the same transcendence and importance globally. This will furnish us with the means to adequately measure the use of the term and, subsequently, to understand its proper range of meaning and significance in institutional, spatial, and scientific spheres.

\section{Conceptualization of the Term "Social Economy"}

Social Economy is a term that first appeared in the scientific literature amid the First Industrial Revolution. At that time, liberal economic theory was already fully preeminent in England and spreading throughout northern Europe. It was a socially complicated time that experienced evermore pronounced economic and social imbalances.

The first author to use this term was Charles Dunoyer, who in 1830 published his work "Nouveau traité d'économie sociale" (Dunoyer, 1830) (Fig. 1) to refer to the need for ethical economic development, adjusted to the needs of people. The term was also later used by other authors such as Cummings (1890) in his article entitled "Social Economy at the Paris Exposition."

In the 1930s, the University of Leuven (Belgium) offered a specialization course on Social Economy (Croca Caeiro, 2008). At the same time, several contributions were made to this scientific and academic concept. This new approach focused on the social aspect of economic activity, which influenced various theorists of the nineteenth century and led to further analysis by other economic thinkers such as Stuart Mill, León Walras, and Charles Gide. This gave rise to the intellectual endorsement of the cooperative movement as a strong reaction to the capitalist production system that was thought to generate inequality by imposing the power of money, and which, ultimately, turned out to be the genesis of the concept of Social Economy (Chaves \& Monzón, 2008a). On the other hand, the influence of several ideologies that evolved in the nineteenth century, including French Utopian Socialism, Scientific Socialism, the Cooperative Movement, Trade Unionism and Christian Solidarity (Piechowski, 2002), or its maximum expression, the Encyclical "Rerum Novarum" of Pope Leo XIII (1891), all contributed to a conceptualization related to the production of goods and services which was outside the parameters of the dominant capitalist principles.

Fig. 1 First Publication to mention "Social Economy"




In Spain, Concepción Arenal (1861) and José Arias de Miranda (1862) were already working on a social economy concept that was directly linked individuals and the State's activity to the provision of social care and charity services.

Social Economy and the cooperative movements are two realities that arose simultaneously and fed off each other, and hence, the Social Economy cannot be understood without its primary reference to cooperative societies. In the dominant intellectual sense, the phrase Social Economy has been that of an actual process, the cooperative movement, making it even to this day, the backbone of an institutional sector (Monzón, 1996). Due to the rise of the cooperative movement and its practical materialization, at the scientific level, the term social economy is declining in favor of a more precise one, that of the Cooperative Sector (Chaves, 1999). Spanish Law 5/2011 on Social Economy states that "The historical framework of the modern concept of Social Economy is structured through the first cooperative experiences."

Focusing on the Social Economy, in and of itself, after the Second World War, with the momentum provided by the Marshall Plan and the economic boom that ensued in Europe, there was a decline in the social and intellectual assessment of issues related to an economy based on unlimited growth (Sánchez Prieto, 2001). The so-called "French May 68" brought about a new relationship between the State and civil society, to the benefit of the second (Pérez de Mendiguren et al., 2008), which strengthened their capacity to act and a leap towards legitimation through recognition of the associative fact (Duverger, 2016). Again, in France, in the 1970s, the socalled National Committee of liaison des activités co-operatives, mutuelles et associatives (CNLAMCA) was established (Chaves, 2008), which, together with other entities such as the Féderation Nationale de the Mutualité Française (FNMF) or the Groupement National de la Cooperation (GNC) adopted the term social economy and made a great effort to implement an updated notion of it. In June 1980, these entities signed the "Charte de l'économie sociale," where the term's concept is generally outlined in the form we know today. (Duverger, 2014).

The Charter framed the Social Economy exclusively within the sphere of entities that took the form of cooperatives, mutual societies, associations and, later, foundations, and focused on internal democracy and the equal treatment of its members, but without any projection of parameters such as respect for the physical environment or sustainability. Only a generic mention that "its purpose is human service" (article 7 of the Charter) brought it closer to the current conception of the Social Economy and its projection on the environment.

In April 2002, the Permanent European Conference of Cooperatives, Mutual Societies, Associations and
Foundations (CEP-CEMAF), the predecessor of the current Social Economy Europe, created the Charter of Principles of Social Economy, which represented a turning point in the theoretical conceptualization of the term (Fajardo, 2018). It establishes the following defining principles of the Social Economy (Monzón Campos \& Chaves Ávila, 2008b):

- The primacy of the individual and the social objective over capital;

- Voluntary and open membership;

- Democratic control by its members (does not concern foundations, as they have no members).

- Combination of the interests of the members/users and/ or the general interest

- Defense and application of the principles of solidarity and responsibility.

- Autonomous management and independence from public authorities.

- Use of most of the profits to pursue sustainable development objectives, services of interest to members, or general interest.

Parameters are already being incorporated beyond the very structure of the organizations that make up the Social Economy, such as the achievement of sustainable development and the general interest.

In parallel to these private institutional declarations, European authorities have taken steps concerning the qualification and recognition of the social economy as a necessary element in developing all States and Nations of the European Union. Thus, initially, within the Commission of the European Communities, a brief concept of Social Economy was drafted on December 18, 1989, defining it as "Companies whose productive activity is based on specific organization techniques: solidarity, participation, and autonomy," but without mentioning the democratic nature of its structure or its relationship to the private sector (Arana Landín, 2012), issues that were later taken into consideration by that body. Various documents were also published by other institutions of the EU, such as:

- The expert opinion of the Economic and Social Committee to the Council of the 19th of September, 1990 on "Companies in the social economy and the completion of the European market without borders."

- The expert opinion of the Economic and Social Committee of the 5th of July, 2017 on "The external dimension of the social economy."

- Within the European Parliament, the Social Economy Intergroup has been in operation since 1990 and has issued reports, some as notable "Toia Report" of the 26th of January, 2009, on the social economy. 
- The Council of the European Union's approval on the 7th of December, 2015 of the resolution on "The promotion of the Social Economy as a key engine of economic and social development in Europe" incorporating these parameters.

- The holding of successive annual conferences since 1989 on the Social Economy, with their corresponding proceedings.

In the European Union, the fundamental role played by the social economy sector in the economic space is highlighted. The recent Regulation (EU) 2021/241 of the European Parliament and of the Council of 12 February 2021, which establishes the Recovery and Resilience Mechanism, contemplates the need to introduce reforms and investments of the Member States of the European Union in the promotion of the Social Economy for this recovery, pointing out as one of the fields of intervention the support to the Social Economy and social enterprises, evincing that political, legislative, and executive efforts are necessary for its development. It is also working towards greater homogeneity (a homogeneity which is yet to materialize) of the European statutes connected to associations, foundations, and mutual societies, similar to the regulatory framework developed for the cooperative sector in Council Regulation CE 1435/2003. The need for developing statistics is also recognized, and the sector's acceptance as an active agent in dialog and the social pact to achieve the goals of the Europe 2020 Strategy.

As already stated in the report prepared by CIRIEC for the European Economic and Social Committee on the Social Economy in the European Union in 2008, the Social Economy has had different theoretical approaches, and has been identified, to a large extent, with other terms such as the third sector, non-profit organizations-proper to the English-speaking world—or the solidarity economy—very widespread in France and Latin America (Monzón \& Chaves, 2008a, b), and with other new terms that are currently being used and developed in the scientific literature around the idea of generating wealth as an alternative to capitalism, and which are not merely synonymous with the Social Economy. Among the terms that scientific production is using and developing for this broad concept of wealth generation with parameters far removed from capitalist logic, the following concepts can be highlighted: Social Economy, Nonprofit Sector (Hansmann, 1980); Nonprofit Organizations (NPO); Voluntary Sector (Pérez de Mendiguren, 2008); Social Enterprises and Third Sector (Defourny \& Develtere, 2009; Evers \& Laville, 2004); Solidarity Economy, Social Economy and Solidarity, Gemeinwirtschaft (Bilkhölzer, 2006); Economy of Communion (Bruni \& Héjj, 2011); Civil Economy (Zamagni, 2008); Economy for the Common Good (Felber \&
Haglberg, 2017); Collaborative Economy (Carrasco, 1996; Díaz-Foncea et al., 2016); Social Enterprises (Defourny \& Nyssens, 2007); Social Innovation (Moulaert et al., 2013); Circular Economy (Kirchherr et al., 2017); Social impact business (Spiegel, 2011); Social Entrepreneurship (Enciso et al., 2012); Popular Economy (Larraechea \& Nyssen, 1994; Chaves \& Monzón, 2008: 32); Fourth Sector (Alessandrini, 2002); Alternative Economic Practices (Fickey, 2011); Benefit Corporations (Brakman Reiser, 2011); Corporate Social Responsibility (Lizcano, 2006); Plural Economy (Laville, 2013); Labor Economy (Coraggio, 2007); Matristic Economy (Arruda, 2004) or Diverse Economy (Gibson-Graham, 1996; Kraus et al., 2020; McKinnon et al., 2020).

The development and use of all these new terms "have emerged from the questioning of the hegemonic economic model based on the traditional lucrative enterprise and incorporate a propositional burden that places the social and environmental dimension in a central position in the economy" (Chaves \& Monzón, 2018). These dimensions justify the social economy and form the nucleus of the concept.

Disparities with regards to its denomination also exist among the different countries of the European Union, for example (Alfonso Sánchez, 2010):

- In Spain, Law 5/2011 defines the Social Economy as the set of entities not belonging to the public sector that, with democratic operation and management and equal rights and duties of the members, practice a special regime of property and distribution of earnings, using surpluses for the year for the growth of the entity and the improvement of services to partners and society.

- In the UK, Denmark, Malta, and Slovenia, the concepts of Voluntary Sector and Non-Governmental Organizations are more closely related to the concept of Nonprofit Organizations and enjoy wide scientific, social, or political recognition. These are organizations dedicated to particular social causes or social advocacy. In economic terms, they are organizations that use their surplus income to achieve their final objective rather than distributing their income to the organization's shareholders, leaders, or members. Nonprofit organizations are exempt from taxes. They can operate in religious, scientific, research, or educational settings (Weisbrod, 1988).

- In French-speaking European countries (France, Belgian Wallonia, and Luxembourg) and Greece, the concepts of Solidarity Economy and Social and Solidarity Economy are also recognized. This is the branch of the economy comprised of companies and organizations in the private sphere that seek to reconcile economic activity and social goals. Their objectives are 
not the mere distribution of profits, but rather are governed democratically, with management based on the entity's economic strengthening for maintaining the activity. They are legally constituted as cooperatives, mutual societies, foundations or associations, and mercantile companies that meet similar performance and operational criteria as other entities and register as such in their corresponding Mercantile Registry (Draperi, 1992; Demoustier, 2001; Favreau, 2005; Duverger, 2014; Glémain \& Richez-Battesti, 2018; Swaton, 2018).

- In the Germanic countries (Germany and Austria), it is related to the notion of Gemeinwirtshaft (economy of general interest). It refers to economic structures whose objective is not the pursuit of private profit but rather of the common good, including the public sphere, made up mainly of unions and cooperatives.

- In the Nordic countries (Sweden, Norway, and Finland), the Ideell organization is envisaged. These are private, nonprofit organizations that operate through volunteering. Often interpreted as "ideal" in the broad sense, it can operate in a wide range of fields such as human rights issues, humanitarian efforts, and environmental issues.

- In Italy, the term Social Economy has not been widely used. The movement or conglomerate comprising cooperatives and other similar forms of organization have not been considered in the scientific literature or at the political level (Briganti, 1990). Instead, they refer to the field of cooperatives or mutual societies with the term "associativism," "cooperative enterprises," or the "mutualist movement" to refer to both. Since the 1980s, the term "L'impresa sociale" has been used to refer to traditional nonprofit organizations that deliver social services and activities. However, since the 1990s, the term has been increasingly used in the scientific and legislative field to describe entrepreneurial initiatives in sectors other than the original cooperatives and mutual societies. It is increasingly the goods and services that define an enterprise as social in terms of its objectives and how production is carried out. Consequently, ethical finance, micro-credits, fair trade, and in general, initiatives for the production of goods and services, including private ones, which aim to achieve objectives other than the profit of the owners, are increasingly seen as social enterprises. (Borzoga, 2009).

In short, as numerous authors point out (Fajardo, 2018; Monzón Campos, 2017; Pérez de Mendiguren \& Etxezarreta, 2015), the imprecision of the Social Economy concept seems more broadly associated with its dissemination and popularization than with research and theoretical debate since the concept of the social economy has been developed fairly homogeneously by both policymakers and social actors. Thus, the term of social economy is still in a pre-paradigmatic stage, in the midst of a change process, a change reflected in the initial drafts of social economy laws of several European countries (Asiminei \& Şoitu, 2014). Consequently, its positivist conceptualization in a legal text, which could then be enacted and enforced for institutions, entities, and individuals, currently lacks concreteness. Indeed, it is precisely for this reason that this article aims to analyze the use of the term Social Economy and its level of scientific production employing a bibliometric analysis using the WoS (JCR) and Scopus (SJR) databases, leading to the establishment of newly trending topics and lines of research for other terms and contents used in scientific production and related to a production model far removed from capitalist parameters of return on investment, which will help, comparatively, to reach a more precise specification of the content of the Social Economy and its relationship with other terms and content centered on economic development that seeks the improvement of people and their physical surroundings, and the preservation of the environment.

\section{Materials and Methodology}

A bibliometric analysis has been performed to study the evolution of the concept of "social economy. " By using statistical and mathematical techniques (Osareh, 1996), this method evaluates research results (Pritchard, 1969) at various levels (by countries, authors, journals, and research centers, among others). It is a widely accepted scientific method used by leading research institutions such as the National Science Foundation or the European Commission (Reuters, 2019). According to the OECD (2002), bibliometric analysis is defined as "the statistical analysis of books, articles, or other publications to measure the "output" of individuals/research teams, institutions, and countries, to identify national and international networks, and to map the development of new (multidisciplinary) fields of science and technology." Furthermore, the h-index has also been used to explain the performance or production of the research work. It is defined as the " $x$ " number of articles with a total number of $\geq$ " $x$ " citations so that those articles have been cited at least " $x$ " times (Hirsch, 2005).

A series of steps have been followed in the bibliometric analysis (Fig. 2). First, the search criteria, the keywords, were defined. In this article, we have chosen to use the expression "social economy." Within the scope of legislative development at an international level, pan-EU institutions, individual Member States, and other leading countries around the world, and the development of academic and institutional scientific production, the term 


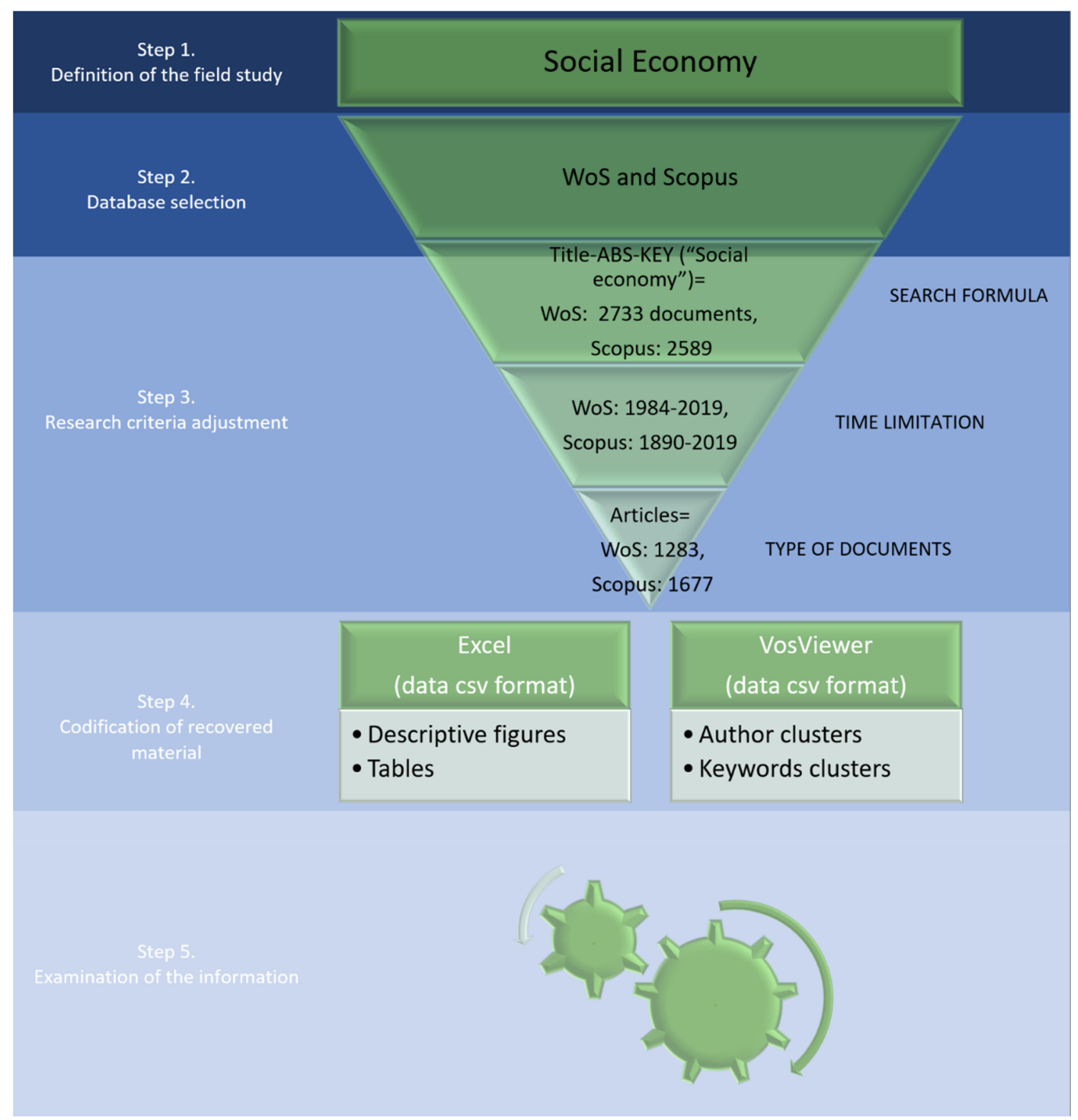

Fig. 2 The Dataset assembling process

Social Economy is acquiring greater prominence for promoting policies and scientific development that are focused on people, the environment and social environment beyond mere economic growth. Although the term social economy is only one of several terms used to incorporate nuances, different visions, or more specific objectives related to this scientific field, it is one of the earliest terms used to describe this new vision of wealth focused on people and their environment and the only the term used for this research.

Secondly, the databases used in the analysis were defined. Specifically, Scopus and WoS were selected to perform the analysis since they are the two most relevant data sources, which, unlike Google Scholar, adhere to rigorous protocols that ensure that the articles they include are of the highest quality (Orduña et al., 2015).

The chronological limits of the documents to be included in the research were then established. The study encompasses the period from the first article registered in each database until the year 2019. In WoS, the first article on the social economy was published in 1984 , while in the case of Scopus, it was 1890 .

In total, the articles, books, conference proceedings, and other research documents included in the main collection of Web of Science (WoS) and Scopus added up to a total of 2733 and 2589 publications, respectively (Table 1). Finally, only articles have been considered, thus excluding, proceedings, reviews, books, and book chapters. 
Table 1 Distribution of publications by type of document

\begin{tabular}{lll}
\hline Type of document & WoS & Scopus \\
\hline Articles & 1283 & 1677 \\
Proceedings & 1158 & 622 \\
Reviews & 179 & 97 \\
Books and book chapters & 113 & 193 \\
\hline
\end{tabular}

\section{Results and Discussion}

\section{Number of Publications per Year}

The first article registered in the Scopus database is Cummings' work entitled "Social Economy at the Paris Exposition" (1890), which analyzes the main characteristics of the companies that comprise the social economy. Concerning the WoS database, the first article to be included is the study by Maree and Saive entitled "Social economy and cooperative renewal-definition, financing, issues" (1984), in which the definition of social economy and aspects related to its financing are analyzed (Table 2). The big difference regarding the year of the first article registered in each database is that WoS only includes documents from the year 1900 .

Since those first publications, the number of articles has increased steadily and regularly over the years, with Scopus including significantly more articles than WoS throughout the entire period (Fig. 3). Likewise, it is observed that from 2004 onwards, there is an exponential increase in the number of publications. The trigger was the 2002 Charter of Principles of the Social Economy that clarified many conceptual issues.

Conversely, the evolution in the number of citations presents a more irregular trend related to that shown in the number of publications (Fig. 4). Throughout the study period, numerous ups and downs are observed, the number of citations recorded in Scopus being generally higher and both databases reaching their peak in 2011 .

According to Table 3, the most cited articles are the study by Marsden (1999), in which he evaluates the contribution of social economy companies in the management of rural spaces, and that by Moulaert and Ailenei (2005), wherein they analyze the conceptional evolution of the concept of social and solidarity economy. They are followed by the studies of McClanahan et al. (2009), in which the role of the social economy in the sustainability of economic activities such as fishing is studied; that of Gerometta et al. (2005), which evaluates the capacity for innovation of social economy companies to support the challenges faced by twenty-first century cities, and that of Peck and Theodore (2000), who study the capacity of the
Table 2 Annual distribution of publications

\begin{tabular}{|c|c|c|c|c|c|c|c|c|}
\hline \multirow[t]{2}{*}{ Year } & \multicolumn{4}{|c|}{ WoS } & \multicolumn{4}{|c|}{ Scopus } \\
\hline & $\mathrm{A}$ & $\mathrm{TC}$ & TC/A & H-index & A & $\mathrm{TC}$ & TC/A & H-index \\
\hline 1890 & - & - & - & - & 1 & 0 & 0 & 0 \\
\hline 1893 & - & - & - & - & 1 & 2 & 2 & 1 \\
\hline 1908 & - & - & - & - & 1 & 1 & 1 & 1 \\
\hline 1910 & - & - & - & - & 1 & 0 & 0 & 0 \\
\hline 1914 & - & - & - & - & 1 & 0 & 0 & 0 \\
\hline 1926 & - & - & - & - & 2 & 0 & 0 & 0 \\
\hline 1942 & - & - & - & - & 1 & 0 & 0 & 0 \\
\hline 1961 & - & - & - & - & 1 & 1 & 1 & 1 \\
\hline 1963 & - & - & - & - & - & - & - & - \\
\hline 1965 & - & - & - & - & 2 & 3 & 1.5 & 1 \\
\hline 1968 & - & - & - & - & - & - & - & - \\
\hline 1969 & - & - & - & - & 2 & 0 & 0 & 0 \\
\hline 1970 & - & - & - & - & 1 & 0 & 0 & 0 \\
\hline 1972 & - & - & - & - & 1 & 1 & 1 & 1 \\
\hline 1974 & - & - & - & - & 2 & 2 & 1 & 1 \\
\hline 1975 & - & - & - & - & 1 & 0 & 0 & 0 \\
\hline 1976 & - & - & - & - & 2 & 1 & 0.5 & 1 \\
\hline 1977 & - & - & - & - & 1 & 4 & 4 & 1 \\
\hline 1978 & - & - & - & - & 3 & 1 & 0.33 & 1 \\
\hline 1979 & - & - & - & - & 3 & 3 & 1 & 1 \\
\hline 1980 & - & - & - & - & 2 & 0 & 0 & 0 \\
\hline 1981 & - & - & - & - & 8 & 102 & 12.75 & 3 \\
\hline 1982 & - & - & - & - & 3 & 4 & 1.33 & 1 \\
\hline 1983 & - & - & - & - & 4 & 0 & 0 & 0 \\
\hline 1984 & 5 & 2 & 0.4 & 1 & 5 & 19 & 3.8 & 2 \\
\hline 1985 & 2 & 8 & 4 & 2 & 5 & 7 & 1.4 & 2 \\
\hline 1986 & 1 & 5 & 5 & 1 & 4 & 36 & 9 & 2 \\
\hline 1987 & 7 & 7 & 1 & 1 & - & - & - & - \\
\hline 1988 & 1 & 3 & 3 & 1 & 5 & 22 & 4.4 & 2 \\
\hline 1989 & 2 & 0 & 0 & 0 & 4 & 156 & 39 & 2 \\
\hline 1990 & 1 & 0 & 0 & 0 & 4 & 104 & 26 & 2 \\
\hline 1991 & - & - & - & - & 2 & 5 & 2.5 & 1 \\
\hline 1992 & - & - & - & - & - & - & - & - \\
\hline 1993 & 3 & 4 & 1.33 & 1 & 6 & 6 & 1 & 2 \\
\hline 1994 & 2 & 13 & 6.5 & 1 & 4 & 86 & 21.5 & 2 \\
\hline 1995 & 2 & 0 & 0 & 0 & 3 & 1 & 0.33 & 1 \\
\hline 1996 & - & - & - & - & 3 & 2 & 0.67 & 1 \\
\hline 1997 & 4 & 36 & 9 & 3 & 16 & 100 & 6.25 & 6 \\
\hline 1998 & 1 & 7 & 7 & 1 & 6 & 12 & 2 & 1 \\
\hline 1999 & 6 & 259 & 43.17 & 4 & 15 & 361 & 24.07 & 7 \\
\hline 2000 & 3 & 114 & 38 & 2 & 7 & 50 & 7.14 & 4 \\
\hline 2001 & 1 & 21 & 21 & 1 & 11 & 53 & 4.82 & 5 \\
\hline 2002 & 7 & 235 & 33.57 & 4 & 19 & 488 & 25.68 & 8 \\
\hline 2003 & 6 & 145 & 24.17 & 4 & 18 & 221 & 12.28 & 6 \\
\hline 2004 & 4 & 38 & 9.5 & 3 & 15 & 365 & 24.33 & 8 \\
\hline 2005 & 30 & 467 & 15.57 & 8 & 36 & 618 & 17.17 & 10 \\
\hline 2006 & 24 & 138 & 5.75 & 7 & 30 & 419 & 13.97 & 11 \\
\hline
\end{tabular}


Table 2 continued

\begin{tabular}{|c|c|c|c|c|c|c|c|c|}
\hline \multirow[t]{2}{*}{ Year } & \multicolumn{4}{|c|}{ WoS } & \multicolumn{4}{|c|}{ Scopus } \\
\hline & A & $\mathrm{TC}$ & $\mathrm{TC} / \mathrm{A}$ & H-index & A & $\mathrm{TC}$ & $\mathrm{TC} / \mathrm{A}$ & $\mathrm{H}$-index \\
\hline 2007 & 29 & 509 & 17.55 & 9 & 39 & 592 & 15.18 & 11 \\
\hline 2008 & 29 & 195 & 6.72 & 6 & 34 & 361 & 10.62 & 9 \\
\hline 2009 & 55 & 682 & 12.4 & 14 & 53 & 841 & 15.87 & 16 \\
\hline 2010 & 47 & 290 & 6.17 & 9 & 49 & 340 & 6.94 & 9 \\
\hline 2011 & 67 & 786 & 11.73 & 13 & 68 & 897 & 13.19 & 14 \\
\hline 2012 & 78 & 574 & 7.36 & 14 & 83 & 693 & 8.35 & 15 \\
\hline 2013 & 83 & 484 & 5.83 & 11 & 100 & 723 & 7.23 & 13 \\
\hline 2014 & 88 & 644 & 7.32 & 8 & 114 & 871 & 7.64 & 10 \\
\hline 2015 & 91 & 543 & 5.97 & 12 & 106 & 693 & 6.53 & 14 \\
\hline 2016 & 114 & 322 & 2.82 & 9 & 146 & 551 & 3.77 & 11 \\
\hline 2017 & 166 & 493 & 2.97 & 11 & 176 & 791 & 4.49 & 13 \\
\hline 2018 & 164 & 360 & 2.19 & 9 & 211 & 482 & 2.28 & 10 \\
\hline 2019 & 146 & 94 & 0.64 & 4 & 182 & 171 & 0.94 & 6 \\
\hline
\end{tabular}

Notes: $Y$ Year, $A$ Articles, $T C$ Total cites, $H$ H-index

social economy for generating employment effectively and sustainably over time.

\section{Distribution by Subject Area}

The distribution of articles by Subject Area shows a significant concentration in subjects related to economic and business sciences and social sciences. (Table 4). As it can be seen, the area of environmental sciences in the second place in the WoS database shows the growing relevance of environmental issues when addressing the activities of Social Economy enterprises.

\section{Distribution by Institution}

The institution with the largest volume of articles published in both databases is the Chinese Academy of Science, followed by the University of Valencia and the University of Quebec and its network of universities (Table 5).

The Chinese Academy of Science is an organization dedicated to the protection of the environment and human health. The University of Valencia is a higher education institution that stands out in economics, business, and law sciences and its National Center for Research and Information on the Collective Economy (CIRIEC-Spain) is an international benchmark. In contrast, the University of Quebec is part of a network of universities in Canada renowned for its research in public administration, engineering, economics, and environmental sciences. It also part of the Centre Interdisciplinaire de Researche et d'Information Sur les Entreprises Collectives, where CIRIEC-Canada has its headquarters.

\section{Distribution by Author}

The distribution by Author shows that the most prolific authors on this subject are Bouchard, in the case of WoS, and Chaves, in the case of Scopus. All authors have pursued this line of research in the second decade of the twenty-first century (Table 6). Bouchard's most cited article is entitled "Social innovation, an analytical grid for understanding the social economy: the example of the Quebec housing sector" (Bouchard, 2012) (23 citations), which evaluates the social economy's role in the innovative resolution of social problems. In his article "The European Social Economic: Concept and dimensions of the third sector" (55 citations), Chaves analyzes the concept of the social economy and its implication within the third sector.
Fig. 3 Evolution in the number of articles

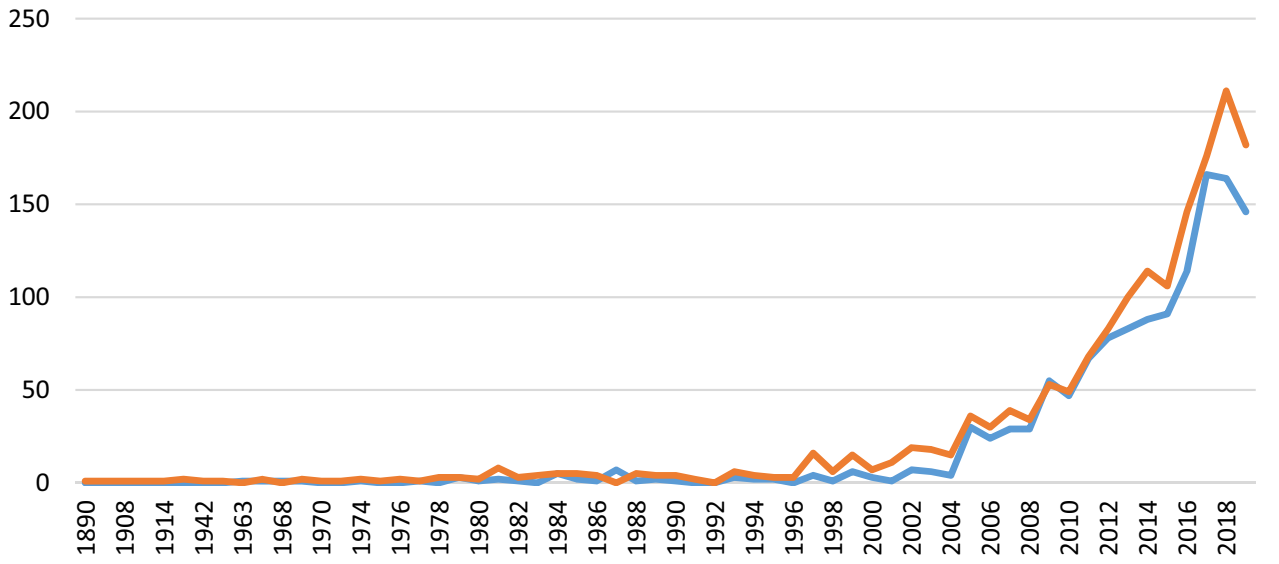

$\longrightarrow$ WoS Scopus 
Fig. 4 Evolution in the number of citations

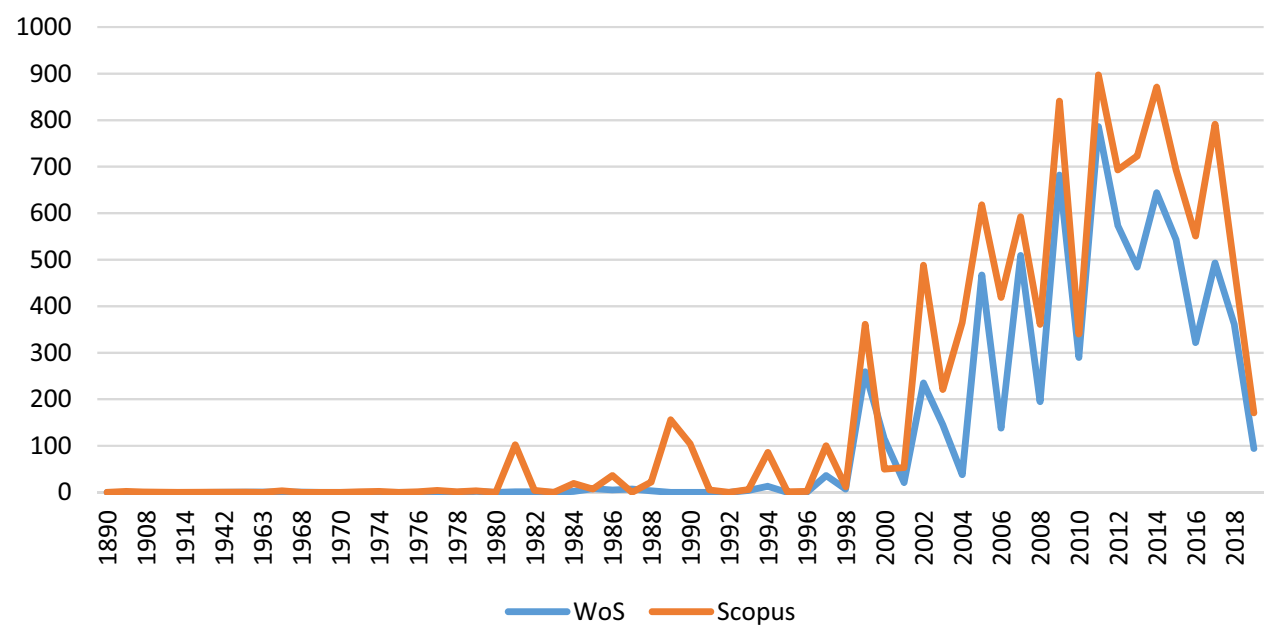

Table 3 The ten most cited articles

\begin{tabular}{|c|c|c|c|c|c|}
\hline No & Author & Title & Journal & Country/institution & $\begin{array}{l}\text { TC } \\
\text { (Average } \\
\text { WoS/ } \\
\text { scopus) }\end{array}$ \\
\hline 1 & $\begin{array}{l}\text { Marsden, T. } \\
\text { (1999) }\end{array}$ & $\begin{array}{l}\text { Rural futures: the consumption countryside and } \\
\text { its regulation }\end{array}$ & $\begin{array}{l}\text { Sociologia } \\
\text { ruralis }\end{array}$ & UK/Cardiff Univ & 183 \\
\hline 2 & $\begin{array}{l}\text { Moulaert, F. } \\
\text { and Ailenei, } \\
\text { O. (2005) }\end{array}$ & $\begin{array}{l}\text { Social economy, third sector and solidarity } \\
\text { relations: a conceptual synthesis from history to } \\
\text { present }\end{array}$ & Urban studies & $\begin{array}{l}\text { UK/Univ. Newcastle and France/ } \\
\text { Univ. Lille }\end{array}$ & 131 \\
\hline 3 & $\begin{array}{l}\text { McClanahan, } \\
\text { T.R. et al. } \\
\text { (2009) }\end{array}$ & $\begin{array}{l}\text { Healing small-scale fisheries by facilitating } \\
\text { complex socio-ecological systems }\end{array}$ & $\begin{array}{l}\text { Reviews in fish } \\
\text { biology and } \\
\text { fisheries }\end{array}$ & $\begin{array}{l}\text { USA/ Wildlife Conservat Soc. } \\
\text { Chile/Pontif. Univ. Catol. } \\
\text { Uruguay/UNDECIMAR }\end{array}$ & 110 \\
\hline 4 & $\begin{array}{l}\text { Gerometta, J. } \\
\text { et al. (2005) }\end{array}$ & $\begin{array}{l}\text { Social innovation and civil society in urban } \\
\text { governance: Strategies for an inclusive city }\end{array}$ & Urban studies & Germany/Humboldt Univ & 107 \\
\hline 5 & $\begin{array}{l}\text { Peck, J. and } \\
\text { Theodore, N. } \\
\text { (2000) }\end{array}$ & Beyond "employability" & $\begin{array}{l}\text { Cambridge } \\
\text { journal of } \\
\text { economics }\end{array}$ & $\begin{array}{l}\text { USA/Univ. Wisconsin and Univ. } \\
\text { Illinois }\end{array}$ & 104 \\
\hline 6 & $\begin{array}{l}\text { Haugh, H. and } \\
\text { Kitson, M. } \\
\text { (2007) }\end{array}$ & $\begin{array}{l}\text { The Third way and the third sector: new labour's } \\
\text { economic policy and the social economy }\end{array}$ & $\begin{array}{l}\text { Cambridge } \\
\text { journal of } \\
\text { economics }\end{array}$ & UK/Judge Business Sch & 92 \\
\hline 7 & $\begin{array}{l}\text { Narushima, } M . \\
\text { (2005) }\end{array}$ & $\begin{array}{l}\text { 'Payback time': community volunteering among } \\
\text { older adults as a transformative mechanism }\end{array}$ & $\begin{array}{l}\text { Ageing and } \\
\text { society }\end{array}$ & Canada/Univ. Toronto & 75 \\
\hline 8 & $\begin{array}{l}\text { Curtis, F. } \\
\text { (2003) }\end{array}$ & Eco-localism and sustainability & $\begin{array}{l}\text { Ecological } \\
\text { economics }\end{array}$ & USA/Drew Univ & 73 \\
\hline 9 & $\begin{array}{l}\text { Reed, D. } \\
\text { (2009) }\end{array}$ & $\begin{array}{l}\text { What do corporations have to do with fair trade? } \\
\text { positive and normative analysis from a value } \\
\text { chain perspective }\end{array}$ & $\begin{array}{l}\text { Journal of } \\
\text { business } \\
\text { ethics }\end{array}$ & Canada/York Univ & 72 \\
\hline 10 & $\begin{array}{l}\text { Evans, M. and } \\
\text { Syrett, S. } \\
\text { (2007) }\end{array}$ & $\begin{array}{l}\text { Generating social capital? the social economy } \\
\text { and local economic development }\end{array}$ & $\begin{array}{l}\text { European urban } \\
\text { and regional } \\
\text { studies }\end{array}$ & UK/Middlesex Univ & 66 \\
\hline
\end{tabular}

From the perspective of the co-citation network of authors, it is observed that the main focus of citations is linked to the works of Defourny and Monzón (Defourny and Campos, 1992), followed by Salamon, Bouchard, and Levesque (Fig. 5).

\section{Distribution by Journal}

REVESCO and CIRIEC-Spain are the journals with the highest volume of articles published in the WoS and Scopus databases. However, the journal Voluntas has the highest productivity level regarding the number of citations 
Table 4 Distribution by subject area

Table 5 Distribution by institution

Table 6 Distribution by author

\begin{tabular}{llll}
\hline Subject areas WoS & Articles & Subject areas scopus & Articles \\
\hline Economics and business & 448 & Social sciences & 741 \\
Environmental sciences & 122 & Economics ad business & 532 \\
Public administration & 71 & Engineering & 258 \\
Social sciences interdisciplinary & 68 & Environmental sciences & 316 \\
\hline
\end{tabular}

\begin{tabular}{|c|c|c|c|c|c|c|c|c|}
\hline \multirow[t]{2}{*}{ Institution } & \multicolumn{2}{|c|}{ Articles } & \multicolumn{2}{|c|}{ Total cites } & \multicolumn{2}{|l|}{$\mathrm{TC} / \mathrm{A}$} & \multicolumn{2}{|c|}{ H-Index } \\
\hline & $\mathrm{W}$ & $S$ & $\mathrm{~W}$ & $S$ & $\mathrm{~W}$ & $S$ & $\mathrm{~W}$ & $\mathrm{~S}$ \\
\hline Chinese Academy of Sciences & 54 & 102 & 887 & 1266 & 16.43 & 12.41 & 14 & 15 \\
\hline University of Valencia & 42 & 34 & 217 & 284 & 5.17 & 8.35 & 7 & 9 \\
\hline University of Quebec & 34 & 19 & 153 & 201 & 4.5 & 10.58 & 7 & 9 \\
\hline Inst.Geog.Scienc.Natur.Resour & 24 & 33 & 169 & 286 & 7.04 & 8.67 & 7 & 10 \\
\hline University of Zaragoza & 20 & 16 & 48 & 52 & 2.4 & 3.25 & 4 & 5 \\
\hline University of Sevilla & 18 & 10 & 41 & 32 & 2.28 & 3.2 & 4 & 4 \\
\hline Beijing University & 16 & 27 & 43 & 82 & 2.69 & 3.04 & 4 & 6 \\
\hline Univ. Del País Vasco & - & 17 & - & 72 & - & 4.24 & - & 5 \\
\hline Univ. Complutense de Madrid & 9 & 7 & 22 & 13 & 2.44 & 1.86 & 3 & 2 \\
\hline
\end{tabular}

Notes: W: WoS; S: Scopus

\begin{tabular}{|c|c|c|c|c|c|c|c|c|c|c|}
\hline \multirow{2}{*}{ Author } & \multicolumn{2}{|c|}{ Articles } & \multicolumn{2}{|c|}{ Total Cites } & \multicolumn{2}{|c|}{$\mathrm{TC} / \mathrm{A}$} & \multicolumn{2}{|c|}{ H-Index } & \multirow{2}{*}{ 1st Article } & \multirow[t]{2}{*}{ Last Article } \\
\hline & W & $\mathrm{S}$ & $\mathrm{W}$ & $S$ & W & $S$ & W & $\mathrm{S}$ & & \\
\hline Bouchard, M.J & 10 & 5 & 45 & 50 & 4.5 & 10 & 4 & 4 & 2006 & 2016 \\
\hline Romero, N.E.C & 8 & - & 0 & - & 0 & - & 0 & - & 2018 & 2018 \\
\hline Levesque, B & 7 & - & 5 & - & 0.71 & - & 1 & - & 2005 & 2017 \\
\hline Rousseliere, D & 7 & 5 & 22 & 25 & 3.14 & 5 & 3 & 3 & 2009 & 2018 \\
\hline Palacio, J.R.S & 6 & 3 & 15 & 18 & 2.5 & 6 & 2 & 2 & 2009 & 2017 \\
\hline Zhang, Y & 6 & - & 36 & - & 6 & - & 4 & - & 2014 & 2019 \\
\hline Chaves, R & 4 & 10 & 96 & 161 & 24 & 16.1 & 3 & 6 & 2002 & 2019 \\
\hline Petrescu, C & - & 6 & - & 16 & - & 2.67 & - & 2 & 2012 & 2018 \\
\hline Arpinte, D & 3 & 5 & 36 & 29 & 12 & 5.8 & 3 & 2 & 2010 & 2017 \\
\hline
\end{tabular}

Notes: W: WoS; S: Scopus

per published article (Table 7). REVESCO is a quarterly journal that publishes original research papers that contribute to publicizing the latest contributions in the field of Social Economy. CIRIEC-Spain has as one of its pillars of action, disseminating scientific research on the public, social and cooperative economy. Finally, Voluntas is characterized by articles focused on the third sector from a multidisciplinary perspective, including economics, law, psychology, or sociology.

\section{Distribution by Country and Language}

The distribution of articles by country shows that Spain, the USA, China, the UK, and Canada are the most relevant countries in both WoS and Scopus (Fig. 6), followed by Italy, Germany, and France. This result coincides with the results obtained in the distribution by institutions.

The distribution by language supports the results obtained from the distribution by institutions and by countries, with English, Chinese, and Spanish predominating as the preferred languages of publication (Table 8).

\section{Analysis of Keywords and Latest Research Trends}

Among the keywords of the articles analyzed, the concept that has the most presence is that of cooperatives (Table 9). In terms of the number of citations received, it is worth highlighting several articles. That by Beckie et al. (2012), 




Fig. 5 Density map of co-citation network

Table 7 Distribution by journal

\begin{tabular}{|c|c|c|c|c|c|c|c|c|}
\hline \multirow[t]{2}{*}{ Source } & \multicolumn{2}{|c|}{ Articles } & \multicolumn{2}{|c|}{ Total Cites } & \multicolumn{2}{|c|}{$\mathrm{TC} / \mathrm{A}$} & \multicolumn{2}{|c|}{ H-Index } \\
\hline & W & $\mathrm{S}$ & W & $\mathrm{S}$ & $\mathrm{W}$ & $\mathrm{S}$ & $\mathrm{W}$ & $\mathrm{S}$ \\
\hline REVESCO & 96 & 81 & 184 & 266 & 1.92 & 3.28 & 6 & 8 \\
\hline CIRIEC Spain & 43 & 42 & 47 & 78 & 1.09 & 1.86 & 4 & 4 \\
\hline International Journal of Social Economics & 40 & 42 & 112 & 145 & 2.8 & 3.45 & 6 & 6 \\
\hline Annals of Public and Cooperative Economics & 31 & 46 & 206 & 450 & 6.65 & 9.78 & 6 & 11 \\
\hline Review of Social Economy & 23 & 29 & 85 & 199 & 3.69 & 6.86 & 6 & 5 \\
\hline Sustainability & 23 & 23 & 66 & 99 & 2.87 & 4.30 & 5 & 6 \\
\hline Voluntas & 20 & 22 & 118 & 243 & 5.9 & 11.04 & 6 & 8 \\
\hline
\end{tabular}

Notes: W: WoS; S: Scopus

wherein they evaluate the significance of the concentration of farmers in cooperatives for local development; the work by Gutberlet (2015) who carried out a similar analysis, although in this instance, focused on the mining sector in Brazil, and finally, that of Salamon and Sokolowski (2016) who relate these terms to the idea of Third Sector, which is also one of the keywords with a significant presence.

Other keywords worth highlighting are Social Enterprise (Haugh \& Kiston, 2007; Evans \& Syrett, 2007; Defourny \& Kim, 2011) or Entrepreneurship (Amin, 2009; Birch \& Whittam, 2008; Sonnino \& Grigs-Trevarthen, 2013).
However, it should be noted that innovation, sustainability, and sustainable development are among the most widely used terms, evidence of the growing interest of the research community in the social economy that can guarantee sustainability in the global context of climate change.

When spread over several periods, it is possible to see the different keywords' evolution (Fig. 7). The only keyword used consistently throughout the period 1890-2019 is that of cooperatives, which was also the seed of what defines social economy nowadays. 


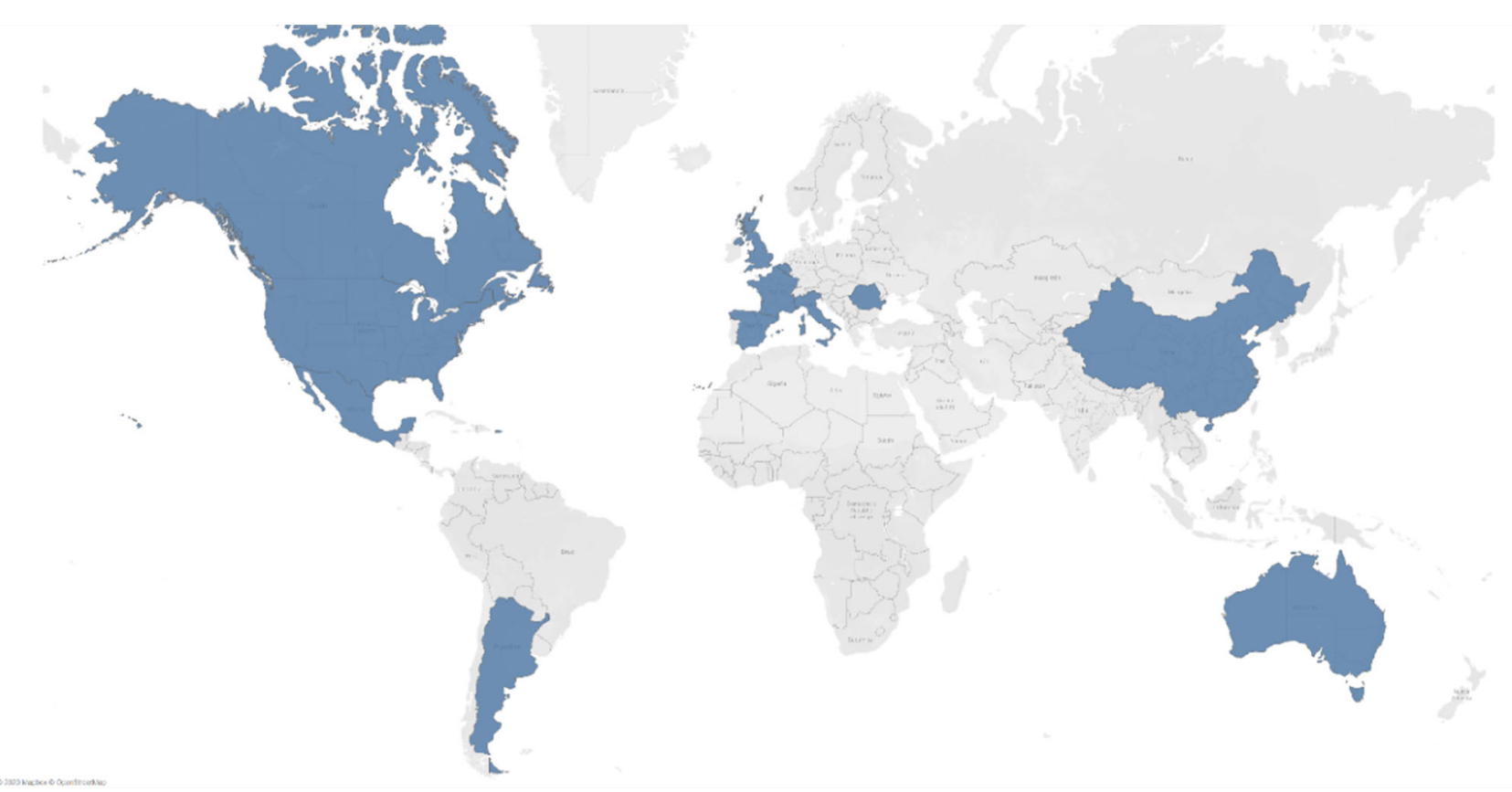

Fig. 6 Distribution by country

Table 8 Distribution by language

From 2000 to the present, there is talk of a social economy model despite the controversy over the term's imprecision (Fajardo, 2018; Monzón Campos, 2017; Pérez de Mendiguren \& Etxezarreta, 2015). China's interest in this concept is also increasingly apparent.

The period 2000-2006 is the most brilliant period for the keyword social economy, coinciding with the Charter of Basic Principles of the Social Economy (Fajardo, 2018). After this period, other keywords have appeared, which on many occasions have acted as substitutes, such as; social enterprise, third sector. Other keywords mentioned outside the top ten are solidarity economy and social enterprises.

There are also new perspectives related to the concept of the social economy, such as entrepreneurship, sustainability, performance, and management. Keywords outside the top ten include governance, sustainable development, innovation, community, impact, and social innovation.

These trends are in line with the analysis of the most recent trends in the period between 2009 and 2019.
Table 9 Most frequently used keywords

\begin{tabular}{lll}
\hline Keyword & Occurrences & $\%$ \\
\hline Social economy & 439 & 9.96 \\
Cooperatives & 92 & 2.09 \\
Social enterprise & 55 & 1.25 \\
Model & 45 & 1.02 \\
Entrepreneurship & 42 & 0.95 \\
Sustainability & 39 & 0.88 \\
Third sector & 38 & 0.86 \\
Performance & 36 & 0.82 \\
Management & 35 & 0.79 \\
Governance & 34 & 0.77 \\
Sustainable development & 31 & 0.70 \\
Solidarity economy & 29 & 0.66 \\
Innovation & 28 & 0.64 \\
Social enterprises & 27 & 0.61 \\
Community & 25 & 0.57 \\
Enterprise & 24 & 0.54 \\
Impact & 24 & 0.54 \\
Sector & 24 & 0.54 \\
Social innovation & 24 & 0.54 \\
\hline & &
\end{tabular}

Figure 8 depicts a pattern of colors, from purple (between 2009 and 2012) to yellow (2019), passing through an intermediate spectrum of shades of green representing the intermediate years (2013-2018). It is observed that, at the beginning of the last decade, the concept of social economy 
Fig. 7 Normalized frequency of occurrence for each keyword among papers published in the time period considered
12

10

8



6



2

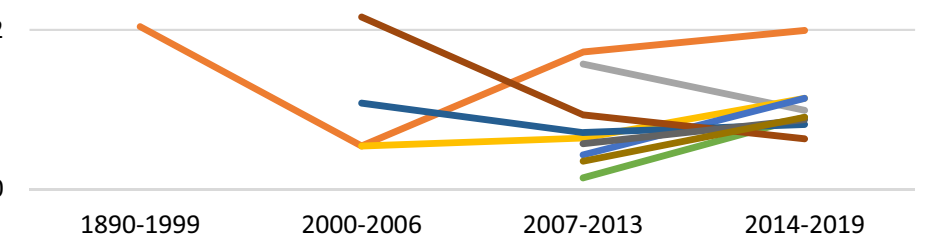

4
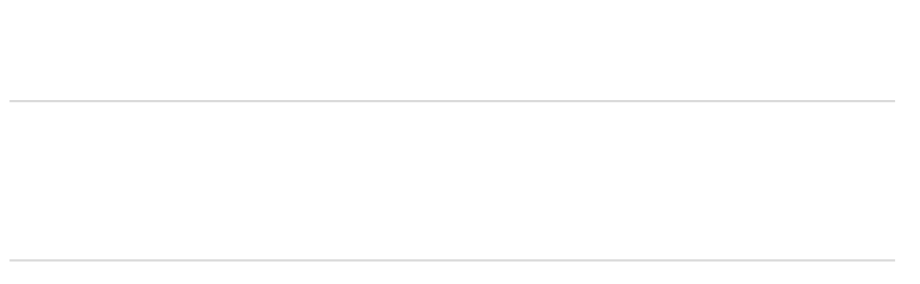

1890-1999

2000-2006

2007-2013

2014-2019

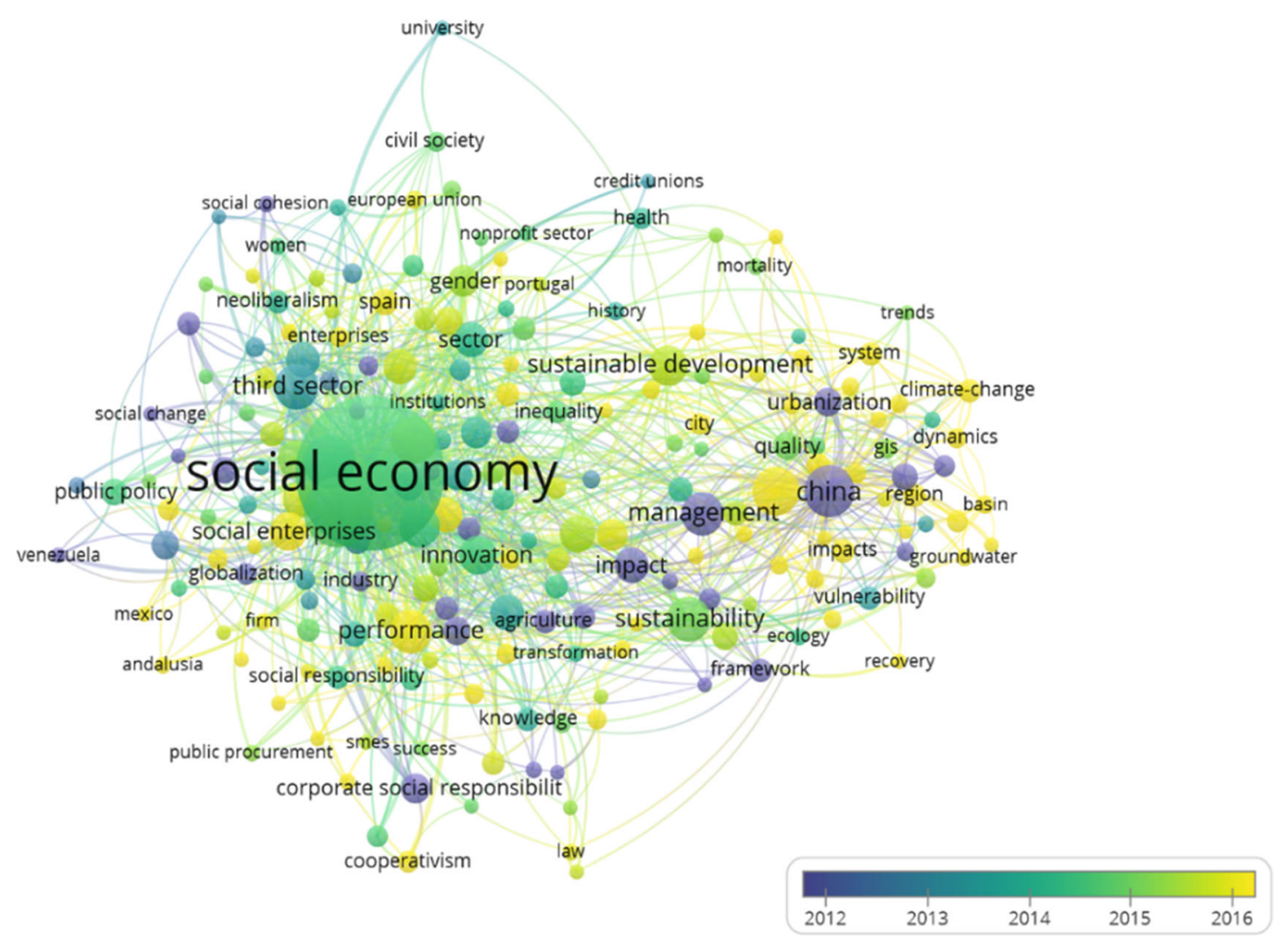

Fig. 8 Keyword cluster by year 
was related, among others, to terms such as corporate social responsibility, social cohesion, globalization, urbanization, and agriculture. As the theme progresses chronologically, it incorporates gender, public policy, sustainable development, health, and the third sector. Finally, aspects such as climate change, performance, or cooperativism appear in the final year. Taken together, this shows that the concept of social economy, in 2019, has evolved from a mere form of corporate social responsibility to be seen as a new way of posing economic activity that reconciles purely business objectives (such as efficient performance) with essential aspects of sustainable development (sustainability and climate change) and transversal issues such as gender. Alongside this evolution, a trend is also observed in geographical areas: while territories such as China or Venezuela stand out at the beginning of this last decade, the most prominent in 2019 was Mexico, or the European Union.

As shown in Fig. 9, the keywords are concentrated in five main groups through a cluster analysis by topic. On the one hand, and represented in blue (both light and dark blue), is the link between the social economy with globalization, the third sector, public policy, and social responsibility in the context of Latin American countries such as Venezuela and Mexico. The yellow cluster includes concepts related to innovation, social change, and corporate social responsibility in the geographical area of Spain. Likewise, the color red revolves around sustainable development, climate change, sustainability, ecology, and urbanization, and as mentioned, there is a close connection between these terms. The green cluster focuses on the relationship between the social economy with higher research centers within the European Union (particularly Portugal). Finally, the orange group focuses on the importance of gender issues and women's empowerment in the social economy.

These results coincide with the comparative analysis of the words in the abstract and titles of all the articles related to this study's subject to learn which words are the most repeated and, therefore, key. A distribution in three clusters is observed (Fig. 10). On the one hand, represented in blue, there are articles framed in the context of China that focus

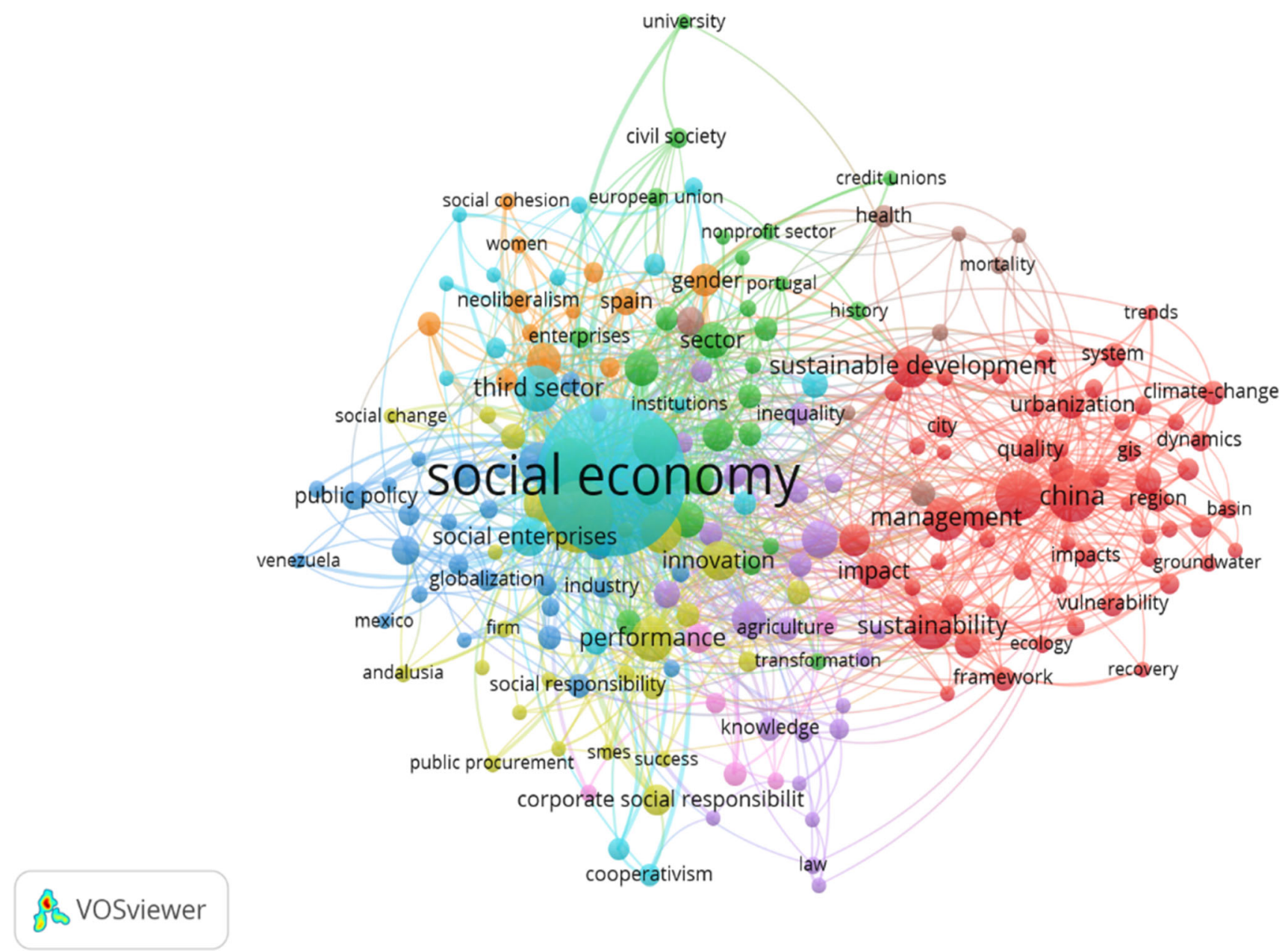

Fig. 9 Cluster analysis of keywords by subject theme 


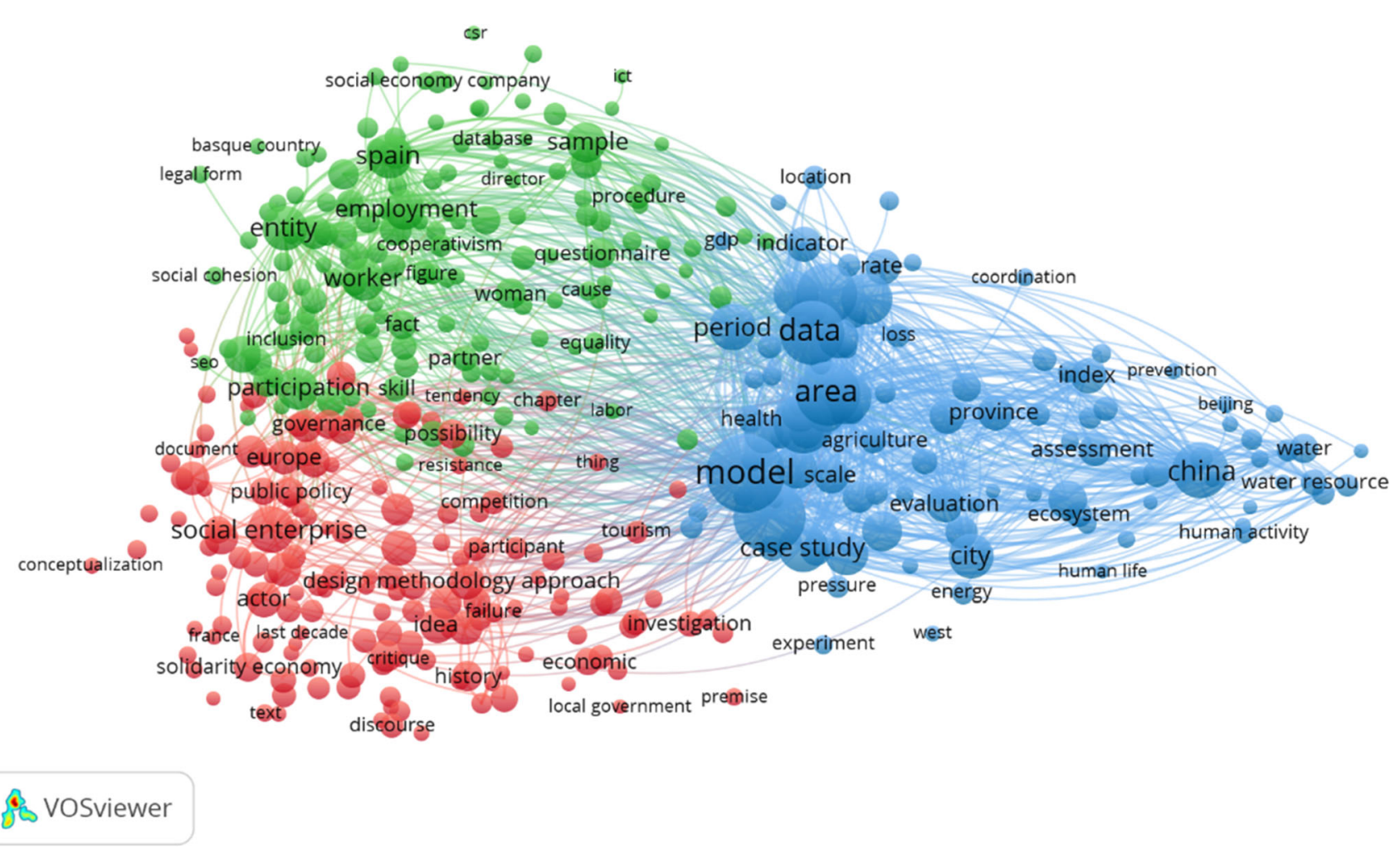

Fig. 10 Cluster by topic of words used in abstract and title of articles

on developing social economy models in the energy sector and on the management of water resources for the improvement of the population's quality of life. The green cluster includes all the articles focused on Spain, dealing with social cohesion, the gender approach, issues related to work-life balance, and equality. Finally, in red are articles framed in the context of the European Union that relate social economy concepts with terms such as social enterprise, the third sector, resilience, solidarity economy, and local government. Thus, the three geographical aspects of the social economy (China, Spain, and Europe) are associated with a specific theme (energy, equality, and conceptualization).

In light of these results, the foreseeable development of the lines of research that are being opened up on the social economy in the coming years related to other terms-and their content- that are developing in the world's scientific output is determined by several principal aspects. Firstly, the acceleration of the climate change process at a global level highlights the need to implement renewable energy generation solutions (solar, wind, biomass) or install green infrastructures that provide environmental services to urban population centers. These solutions can be carried out by social economy entities that promote solidarity and collaborative economy processes. Secondly, the social economy must promote equality at all levels (labor, institutional, social, economic, and so on), making it easier for workers to balance their work and family life without loss of income, especially in the rural areas, where the wage gap between men and women is wider (Parvathi \& Thamizhchelvi, 2020). In fact, social economy entities can reduce the development gaps between urban and rural territories by implementing projects based on endogenous resources of the territory, similar to the organization of the San Fermin festival in Pamplona, Spain (Macías Ruano et al., 2020). Finally, the social economy must continue to advance along its conceptual path to stabilize, define and differentiate it from other similar concepts such as the solidarity or collaborative economy.

\section{Conclusions}

Almost two centuries have passed since the first work related to the social economy by Charles Dunoyer. Despite this, there is still no agreed definition either internationally or within the European Union itself to this day. Examples of this are the many terms encompassing the concept (Social Economy, Nonprofit Sector, Social Enterprises, and Third Sector, Volunteer Sector). Another critical issue that also makes conceptual analysis difficult is its diversity depending on the territorial areas being studied and their different nuances and contexts. 
In general terms, it can be stated that in the social economy, the generation of wealth is not oriented towards ownership of the means of production but rather towards the agents involved in the activity that generates it in order to achieve a fair and equitable distribution of wealth.

The first article registered in the Scopus database is the article by Cummings (1890) entitled "Social Economy at the Paris Exposition." In the case of WoS, the first publication is the study by Maree and Saive (1984) entitled "Social economy and cooperative renewal-definition, financing, issues."

In 2004 was an increase in publications on this topic, at the same time as the publication of the Charter of Principles of the Social Economy. The most cited document is by Marsden (1999) entitled "Rural Futures: The consumption countryside and its regulation," published in the journal Sociologia Ruralis. The most common subject area linked to the articles is "Economics and Business" in WoS and "Social Science" in Scopus. The institutions most committed to the concept of the Social Economy are the Chinese Academy of Science, followed by the Universities of Valencia and Quebec, the last two associated with CIRIEC.

The author with the highest number of publications is M.J. Bouchard, although the most cited author is $\mathrm{R}$. Chaves. The journals REVESCO and CIRIEC-Spain stand out in Scopus, and Sustainability and Voluntas in WoS. Concerning the trends in keywords, the concept that has the most presence is that of cooperatives due to its intimate historical and conceptual connection. The chronological cluster analysis shows that, at present, the social economy is closely being linked to sustainable development, the empowerment of women, and climate change, derived from the characteristics of social economy institutions, in which the purely economic benefits are diluted in favor of the wellbeing of their local environment.

However, this study is not without its limitations. On the one hand, while the analysis has been restricted to the most influential academic databases (WoS and Scopus), other databases such as Google Scholar could have been considered. In turn, the analysis is restricted to the term Social Economy, which is highly concentrated in certain countries and institutions, biasing the concept to their reality, as shown in Distribution by Institution and Distribution by Country and Language Sections. Furthermore, the work on the Social Economy is published in specialized journals, which makes it challenging to take advantage of the crosscutting nature of the concept by relating it to other disciplines such as the environment or energy. On the other hand, the term Social Economy focuses on cooperatives rather than other forms of business organization.

Regarding the limitations of the concept the research is focused on, the analysis shows that the scientific use of the term "Social Economy" is very localized in the geographical areas of Spain, China, Canada, and England.

It is also clear from the analysis that the scientific treatment of the research field of social economy is limited to very few editorial resources. The scientific sphere is present only in a few specialized journals, making it difficult to link the social economy with aspects of other disciplines such as energy, the environment, or sustainability.

A more generalized rethinking is needed to expand the concept of wealth generation outside capitalist logic focused on people and the environment.

In short, the initial concept of social economy is closely linked to the construction of a working model based on the social and entrepreneurial characteristics of cooperatives and other third sector entities in the interests of economic, social, and environmental sustainability, which will have to be further refined with future scientific and institutional contributions.

As future lines of research, it is worth highlighting, firstly, the need to carry out a bibliometric analysis for each of the concepts associated with the social economy (such as Solidarity Economy or Nonprofit Entities) to compare the results and differentiate the concept of the social economy from the rest. Secondly, it would be interesting to analyze social economy entities' suitability to implement projects related to renewable energies in rural environments aimed at galvanizing their economy. Finally, and analogous to this last line of research, a new direction would be to observe and evaluate the social economy's capacity to resolve the socio-economic effects of the COVID-19 pandemic.

This article's contribution is to analyze the social economy from a bibliometric perspective, including analyzing the evolution of social economy publications, most prolific authors, countries, and institutions that do most research on the subject. Clusters have been created in which the different articles have been characterized according to subject area. Subsequently, the trends in the keywords of articles on the Social Economy were analyzed. In light of the results, the social economy, despite the initial conception given in the 1980 Social Economy Charter, which was focused on the internal organization of the entities it considered as its own -cooperatives, mutual societies and associations. Now, in the field of doctrine and scientific production, Social Economy is opening up to the content of the legal provisions that are being dictated and policies that are being implemented for sustainable economic development that are committed to the social and environmental surroundings, being conceived as a way to manage all resources to meet economic, social, and aesthetic needs. Likewise, respect for cultural integrity, essential ecological processes, biological diversity, and 
systems that support life are essential. Therefore, the social economy can be related to sustainability in the following way:

- Ecological sustainability. That is that the activity carried out by social economy enterprises does not cause irreversible changes in ecosystems.

- Social sustainability. This refers to a social economy enterprise's capacity to contribute to its workers' and the community's wellbeing.

- Cultural sustainability. Social economy enterprises must have the capacity to retain their cultural characteristics, distinct from other types of enterprises.

- Economic sustainability. The economic activity of the members of social economy enterprises' work teams must ensure their viability.

\section{Declarations}

Conflict of interest The authors declare that they have no conflict of interest.

\section{References}

Alessandrini, M. (2002). A Fourth Sector: The impact of neoliberalism on non-profit organisations, Refereed paper presented to the Jubilee Conference of the Australasian Political Studies Association Australian National University, Canberra. Accessed the 14th of April 2020 from https://www.researchgate.net/ profile/Megan_Alessandrini/publication/266409433_A_fourth_ sector_The_impact_of_neo-liberalism_on_non-profit_organisations/ links/55e58b5a08aecb1a7ccbb5f0/A-fourth-sector-The-impactof-neo-liberalism-on-non-profit-organisations.pdf.

Alfonso Sánchez, R. (2010). Algunas consideraciones en torno a la propuesta de Ley Marco de Economía Social. REVESCO, 102, $7-23$.

Amin, A. (2009). Extraordinarily ordinary: Working in the social economy. Social Enterprise Journal, 5(1), 30-49. Accessed the 14th of April 2020 from https://www.emerald.com/insight/ content/doi/https://doi.org/10.1108/17508610910956390/full/ html.

Arana Landín, S. (2012). Sobre el nuevo concepto de economía social en la Ley 5/2011, de 29 de marzo, de economía social en España y sus posibles consecuencias tributarias. GEZKI, 8, 85-110. Accessed 14 April 2020 from https://www.ehu.eus/ojs/index. php/Gezki/article/view/12717/11517.

Arenal de García Carrasco, C. (1861). La beneficencia, la filantropía y la caridad. Colegio de Sordo-Mudos y Ciegos (Ed.), Madrid. Accessed 14 April 2020 from http://www.filosofia.org/aut/001/ 1861are.htm

Arias Miranda, J. (1862). Reseña Histórica de la beneficencia española: principios que convendrá seguir para enlazar la caridad privada con la Beneficencia pública. Imprenta del Colegio de Sordo-Mudos y de Ciegos (Ed.), Madrid, Accessed 14 April 2020 from https://books.google.es/books?hl=es\&lr= $\& \mathrm{id}=3 \mathrm{LLc0CvPzJoC} \& o i=$ fnd $\&$ pg.

Arruda, M. (2004). ¿Qué es la Economía Solidaria? El renacimiento de una sociedad humana matrística. Ecología Politica, 27, 71-76. Accessed 14 April 2020 from http://www.socioeco.org/ bdf_fiche-document-3868_es.html.
Asiminei, R., \& Şoitu, C. (2014). Social economy: A shifting paradigm. Journal of Social Economy, IV, 1, 17-30.

Beckie, M. A., Kennedy, E. H., \& Wittman, H. (2012). Scaling up alternative food networks: Farmers' markets and the role of clustering in western Canada. Agriculture and Human Values, 29(3), 333-345.

Birch, K., \& Whittam, G. (2008). The third sector and the regional development of social capital. Regional Studies, 42(3), 437-450.

Bilkhölzer, K. (2006). Development and Perspectives of the Social Economy or Third Sector in Germany. In A. L. Matthies (Ed.), Nordic civic society organisations and the future of welfare services. A model for Europe? (pp. 343-370). TemaNord, from https://books.google.es/books?hl=es\&lr=\&id=_qXBfKvXuHA C\&oi=. Accessed the 14th of April 2020.

Borzoga, C. (2009). L'impresa sociale. Bruni L., Zamagni S. (a cura di), (pp. 516-526). Available at: http://www.irisnetwork.it/wpcontent/uploads/2010/04/Definizione_impresa-sociale.pdf.

Bouchard, M. J. (2012). Social innovation, an analytical grid for understanding the social economy: The example of the Québec housing sector. Service Business, 6(1), 47-59.

Brakman Reiser, D. (2011). Benefit Corporations - A Sustainable Form of Organization, Wake Forest L., p. 591. Accessed from https://heinonline.org/HOL/LandingPage?handle=hein.journals/ wflr $46 \&$ div $=29 \&$ id $=$.

Briganti, W. (1990). La Economía Social en Italia. CIRIEC-España, 8, 51-59. Available at:https://ciriec-revistaeconomia.es/wp-con tent/uploads/rev10-10.pdf.

Bruni, L., \& Héjj, T. (2011). The economy of communion. In L. Bouckaert \& L. Zsolnai (Eds.), Handbook of Spirituality and Business. London: Palgrave Macmillan.

Chaves Ávila, R. (1999). La economía social como enfoque metodológico, como objeto de estudio y como disciplina científica. CIRIEC-España, 33, 115-139.

Chaves Ávila, R. (2008). La economía social: dos décadas generando empleo, tejido productivo y cohesión social en Europa. In: $L a$ economía social aragonesa: un motor de desarrollo: actas de las I Jornadas de la Economía Social en Aragón, Coor (pp. 71-82). Marcuello Servós, Universidad de Zaragoza. Accessed 14 April 2020 from http://www.eco.uva.es/historico/2008/sem_ecosoc/ micro/PRC.pdf.

Chaves Ávila, R., \& Monzón Campos, J. L. (2018). La economía social ante los paradigmas económicos emergentes: innovación social, economía colaborativa, economía circular, responsabilidad social empresarial, economía del bien común, empresa social y economía solidaria. CIRIEC-España, 93, 5-50.

Chaves Ávila, R., \& Monzón Campos, J. L. (2008). Panorama de la investigación en Economía social. Estudios de Economía Aplicada, 26-I, 29-56. Accessed 14 April 2020 from https:// www.redalyc.org/pdf/301/30114081002.pdf.

Coraggio, J. L. (2007). La Economía Social desde la periferia Contribuciones latinoamericanas (pp. 165-194). Buenos Aires: Altamira.

CrocaCaeiro, J. M. (2008). Economía social: Conceitos, fundamentos e tipología. Revista Katálysis Folrianópolis, 11(1), 61-72.

Cummings, E. (1890). Social economy at the Paris exposition. The Quarterly Journal of Economics, 4(2), 212-221. https://doi.org/ $10.2307 / 1880792$

Curtis, F. (2003). Eco-localism and sustainability. Ecological Economics, 46(1), 83-102.

Defourny, J., \& Develtere, P. (2009). The Social Economy: The worldwide making of a Third Sector. Accessed the 14th of April 2020 from https://orbi.uliege.be/bitstream/2268/13613/1/Chap\% 201\%20Defourny\%20Develtere.pdf.

Defourny, J., \& Campos, M. (1992). Économie sociale. Entre économie capitaliste et économie publique/The Third Sector. 
Defourny, J., \& Nyssens, M. (2007). Defining social enterprise, Social Enterprise. In: M. Nyssens (Ed.) The Crossroads of Market, Public Policies and Civil Society. London.

Defourny, J., Kin, Y., \& Kim, S. Y. (2011). Emerging models of social enterprise in Eastern Asia: A cross-country analysis. Social Enterprise Journal, 7(1), 86-111. Accessed the 14th of April 2020 from https://doi.org/10.1108/17508611111130176/ full/html.

Demoustier, D. (2001). L'économie sociale et solidaire. Syros.

Díaz-Foncea, M., Marcuello Servós, C., \& Monreal Garrido, M. (2016). Economía Social y Economía Colaborativa: Encaje y potencialidades. Revista Industrial, 402, 27-35. Accessed 14 April 2020 from https://zaguan.unizar.es/record/69619/files/ texto_completo.pdf.

Draperi, J. F. (1992). Tour d'horizon sur la recherche en économie sociale en France en 1992. RECMA, Revue Internationale De L'economie Sociale, 42, 49-67.

Dunoyer, B. C. (1830). Nouveau Traité $d$ ' economie sociales. Sauteled et Mesnier Ëditeurs.

Duverger, T. (2014). La reconnaissance législative de l'economie sociale et solidaire, Note, $\mathrm{n}^{\circ}$ 224, Fondation Jean-Jaurès, 1-10. Accessed 14 April 2020 from http://base.socioeco.org/docs/note224.pdf.

Duverger, T. (2016). Les transformations institutionnelles de l'économie sociale et solidaire en France des années 1960 à nos jours. Revue Interventions Économiques, 54, 1-18.

Enciso Santocildes, M., Gómez Urquijo, L., \& Mugarra Elorriaga, A. (2012). La iniciativa comunitaria en favor del emprendimiento social y su vinculación con la economía social: una aproximación a su delimitación conceptual. CIRIEC-España, 75, 55-80. Accessed 14 April 2020 from https://www.redalyc.org/ pdf/174/17425798004.pdf.

Evans, M., \& Syrett, S. (2007). Generating social capital? The social economy and local economic development. European Urban and Regional Studies, 14(1), 55-74.

Evers, A., \& Laville, J. L. (2004). Defining the third sector in Europe. The Third Sector in Europe, 11.

Fajardo García, G. (2018). La identificación de las empresas de economía social en España. Problemática Jurídica, REVESCO, 128, 99-125.

Favreau, L. (2005). Économie sociale et politiques publiques. Cahier CRDC UQO. ISBN 2-89605-198-8

Felber, C., \& Hagelberg, G. (2017). The economy for common good. A workable, transformative ethics-based alternative, The next system project. Accessed the 14th of April 2020 from https:// thenextsystem.org/sites/default/files/2017-08/FelberHagelberg. pdf.

Fickey, A. (2011). The focus has to be on helping people make a living: exploring diverse economies and alternative economic spaces. Geography Compass, 5, 237-248. https://doi.org/10. 1111/j.1749-8198.2011.00418.x

Gerometta, J., Haussermann, H., \& Longo, G. (2005). Social innovation and civil society in urban governance: Strategies for an inclusive city. Urban Studies, 42(11), 2007-2021.

Gibson-Graham, J. K. (1996). The end of capitalism (as we knew it): A feminist critique of political economy. University of Minnesota Press.

Glémain, P., \& Richez-Battesti, N. (2018). De l'économie sociale et solidaire à l'entreprise sociale: entre tournant entrepreneurial et innovation. Une clé de lecture. Marché et Organisations, 31(1), 13-19. https://doi.org/10.3917/maorg.031.0013

Gutberlet, J. (2015). Co-operative urban mining in Brazil: Collective practices in selective household waste collection and recycling. Waste Management, 45, 22-31.

Hansmann, H. (1980). The role of nonprofit enterprise. Yale Law Journal, 89(5), 835-901.
Haugh, H., \& Kitson, M. (2007). The Third Way and the third sector: New labour's economic policy and the social economy. Cambridge Journal of Economics, 31(6), 973-994.

Hirsch, J. E. (2005). An index to quantify an individual's scientific research output. Proceedings of the National Academy of Sciences, 102, 16569-16572.

Kirchherr, J., Rieke, D., \& Hekkert, M. (2017). Conceptualizing the circular economy: An analysis of 114 definitions. Resources, Conservation \& Recycling, 127, 221-232. Accessed the 14th of April 2020 from https://www.sciencedirect.com/science/article/ abs/pii/S0921344917302690.

Kraus, S., Li, H., Kang, Q., Westhead, P., \& Tiberius, V. (2020). The sharing economy: A bibliometric analysis of the state-of-the-art. International Journal of Entrepreneurial Behavior \& Research. https://doi.org/10.1108/IJEBR-06-2020-0438

Larraechea, I., \& Nyssen, M. (1994). Les défis de l'economie populaire au Chili. RECMA, 49(242), 43-53.

Laville, J. L. (2013). Économie sociale et solidaire, capitalisme et changement démocratique. In D. Hiez \& E. Lavillunière (Eds.), (dir) Vers une théorie de l'économie sociale et solidaire. Collection: Droit \& économie sociale et solidaire (pp. 17-32). Paris: Editions Larcier.

León XIII. (1891). Rerum novarum, edit. librería editrice vaticana. Accessed 14 April 2020 from http://www.vatican.va/content/leoxiii/es/encyclicals/documents/hf_1-xiii_enc_15051891_rerumnovarum.html.

Lizcano, J. L. (2006). Buen gobierno y responsabilidad social corporativa. Partida Doble, 182, 20-35. Accessed 14 April 2020 from https://www.aeca.es/old/comisiones/rsc/partidadoble_ buen_gobierno.pdf.

MacíasRuano, A. J., PiresManso, J. R., de Pablo Valenciano, J., \& MarruecosRumí, M. E. (2020). The misericórdias as social economy entities in portugal and spain. Religions, 11(4), 200.

Maree, M., \& Saive, M. (1984). Social economy and co-operative renewal-definition, financing, issues. Annals of Public and CoOperative Economy, 55(1), 35-69.

Marsden, T. (1999). Rural futures: the consumption countryside and its regulation. Sociologia Ruralis, 39(4), 501-526.

McClanahan, T. R., Castilla, J. C., White, A. T., \& Defeo, O. (2009). Healing small-scale fisheries by facilitating complex socioecological systems. Reviews in Fish Biology and Fisheries, 19(1), 33-47.

McKinnon, K., Kennedy, M., Barraket, J., \& DeCotta, T. (2020). Is being in work good for wellbeing? Work integration social enterprises in regional Australia. Australian Geographer, 51(3), 361-375. https://doi.org/10.1080/00049182.2020.1781322

Monzón Campos, J. L. (1996). Raíces y perspectivas de la economía social. Documentación Social, 103, 105-121.

Monzón, J. L., \& Chaves Ávila, R. (2008a). The European social economy: Concept and dimensions of the third sector. Annals of Public and Cooperative Economics, 79(3-4), 549-577.

Monzón Campos, J.L., \& Chaves Ávila, R. (2008b). La Economía Social en la Unión Europea, Comité Económico y Social Europeo. Accessed 14 April 2020 from http://www.eesc.europa. eu/resources/docs/qe-30-12-790-es-c.pdf.

Monzón Campos, J.L., \& Chaves Ávila, R. (2017). Evolución reciente de la economía social en la Unión Europea, Estudio realizado por CIRIEC-Internacional, CES/CSS/12/2016/23406, Comité Económico y Social Europeo. Accessed 14 April 2020 from https://www.eesc.europa.eu/sites/default/files/files/qe-04-17875-es-n.pdf.

Moulaert, F., \& Ailenei, O. (2005). Social economy, third sector, and solidarity relations: A conceptual synthesis from history to present. Urban Studies, 42(11), 2037-2053.

Moulaert, F., MacCallum, D., Mehmood, A., \& Hamdouch, A. (2013). General introduction: the return of social innovation as a 
scientific concept and a social practice. In The International Handbook on Social Innovation: Collective Action, Social Learning and Transdisciplinary Research. Cheltenham UK: Edward Elgar Publishing Limited.

Narushima, M. (2005). Payback time: Community volunteering among older adults as a transformative mechanism. Ageing \& Society, 25(4), 567-584.

OECD. (2002). The measurement of scientific and technological activities frascati manual 2002: Proposed standard practice for surveys on research and experimental development. Cambridge University Press.

Orduña-Malea, E., Ayllón, J. M., Martín-Martín, A., \& López-Cózar, E. D. (2015). Methods for estimating the size of Google Scholar. Scientometrics, 104, 931-949. https://doi.org/10.1007/s11192015-1614-6

Osareh, F. (1996). Bibliometrics, citation analysis and co-citation analysis: A review of literature, I. Libri, 46, 149-158.

Parvathi, S., \& Thamizhchelvi, P. (2020). Gender discrimination in India-A Study. Journal of Xi'an University of Architecture \& Technology, 12(4), 2901-2907.

Peck, J., \& Theodore, N. (2000). Beyond'employability. Cambridge Journal of Economics, 24(6), 729-749.

Pérez de Mendiguren, J. C., \& Etxezarreta, E. (2015). Sobre el concepto de economía social y solidaria: aproximaciones desde Europa y América Latina. Revista de Economía Mundial, 40, 123-143. Accessed 14 April 2020 from https://www.redalyc.org/ articulo.oa? $\mathrm{id}=86641407006$. Accessed 14 April 2020 from http://economiasolidaria.org/files/Economia_social_y_solidaria_ concepto_nociones.pdf.

Pérez de Mendiguren, J.C., Etxezarreta Etxarri, E., \& Guridi Aldanondo, L. (2008). ¿De qué hablamos cuando hablamos de Economía Social y Solidaria? Concepto y nociones afines. IX Jornadas de Economía Crítica, Bilbao.

Piechowski, A. (2002). Las cuatro corrientes ideológicas en los orígenes de la economía social y su impacto en el presente. Primera Conferencia Europea sobre Economía Social en Europa Central y Oriental. Praha Economía Social 2002. Ampliando la Economía Social. Coord. Bruno Roelants. Julio, 37-38. Accessed 14 April 2020 from https://docplayer.es/57985119-
Primera-conferencia-europea-sobre-economia-social-en-europacentral-y-oriental-ampliando-la-economia-social-praga-10-2002. html.

Pritchard, A. (1969). Statistical bibliography or bibliometrics. Journal of Documentation, 25, 348-349.

Reed, D. (2009). What do corporations have to do with fair trade? Positive and normative analysis from a value chain perspective. Journal of Business Ethics, 86(1), 3-26.

Reuters, T. (2019). A guide to evaluating research performance with citation data. Available online from http://ip-science.Thomson reuters.com/m/pdfs/325133thomson.pdf.

Salamon, L. M., \& Sokolowski, S. W. (2016). Beyond nonprofits: Reconceptualizing the third sector. VOLUNTAS: International Journal of Voluntary and Nonprofit Organizations, 27(4), $1515-1545$.

Sánchez-Prieto, J. M. (2001). La historia imposible del Mayo Francés. Revista De Estudios Políticos (nueva Época), 112, 109-133.

Sonnino, R., \& Griggs-Trevarthen, C. (2013). A resilient social economy? Insights from the community food sector in the UK. Entrepreneurship \& Regional Development, 25(3-4), 272-292.

Spiegel, P. (2011). Social impact business-Soziale und ökologische Probleme unternehmerisch lösen. In H. Hackenberg \& S. Empter (Eds.), Social entrepreneurship-Social business Für die Gesellschaft unternehmen (pp. 133-146). VS Verlag für Sozialwissenschaften.

Swaton, S. (2018). Pour une socioéconomie angegée Monnaiee, finance alternatives. Classiquer Garnier.

Weisbrod, B. A. (1988). The Nonprofit Economy. Harvard University Press.

Zamagni, S. (2008). Reciprocity, civil economy, common good. pursuing the common good: how solidarity and subsidiarity can work together. Pontifical academy of social sciences, Acta 14, Vatican City. Accessed the 14th of April 2020 from http://www. pass.va/content/dam/scienzesociali/pdf/acta14/acta14-zamagni. pdf.

Publisher's Note Springer Nature remains neutral with regard to jurisdictional claims in published maps and institutional affiliations. 